\title{
Climate Change: Tourism Destination Dynamics
}

\section{Ralf Buckley}

Research Director, Climate Response, and Director, International Centre for Ecotourism Research, Griffith University, PMB 50 Gold Coast 9726, Australia, e-mail: r.buckley@griffith.edu.au

\section{Introduction}

The increasing attention given to the tourism sector within international negotiations on climate change is documented by Hall (2008); and the industry's potential role in mitigation is explored by Becken in her probe on Climate Change. Here, therefore, I shall outline the ways in which tourist destinations of various types are likely to be affected by climate change, the ways in which they may respond, and the research they will need to inform those responses. In particular, Table 3 of Hall's probe lists much of the relevant literature currently available, and Table 6 in that review compares the relative frequencies with which more detailed subtopics have been referred to. Further information is available in Hall and Higham (2005); Becken and Hay (2007). As noted by Becken (2008) in her response, however, this does not in itself provide a framework for further analysis; nor does that commentary itself adopt such an aim. Here, therefore, I attempt to provide such a framework, make some predictions, and identify research priorities.

\section{Analytical Framework}

There are four main links between tourism and climate change:

- contributions of tourism to climate change, and ways to mitigate or offset them

- increased travel costs because of mitigation measures, and consequences for travel patterns

- changing climates in countries of origin, and effects on outbound and domestic tourism 
- changing climates at destinations, and effects on their attractiveness, safety and comfort.

My focus here is on the last of these. It can be considered in three sub-categories: artificial climates, climatic variability, and climatic means. Artificial climates provide a buffer against climate change, particularly in urban destinations, simply through changing heating and airconditioning. If the natural attractions at a tourism destination are affected by climate change, the simplest response is to substitute artificial attractions: swimming pools instead of beaches, shops instead of ski slopes. Changes to climatic variability include, e.g., more storms and floods, and more droughts and heatwaves leading to wildfires and coral bleaching. Most of these effects are temporary, and various protective measures are available, either through engineering or insurance approaches (Buckley 2007). The tourism industry too can actively adopt such protective measures, either independently or in conjunction with government and other landholders. The main approaches include upgrading buildings and infrastructure, and improving emergency provisions. Changes to climatic means may affect, e.g., skiable snow, beach configurations, river flows and lake levels, icon wildlife species, and so on. The principal response is to change the tourism products on offer, re-position the destination accordingly, and target new markets.

\section{Regional Patterns}

The ski industry is particularly vulnerable to warming and to reduced precipitation, since these changes reduce both natural snow cover, and opportunities for snow-making. Ski resorts in North America and Europe, Australia and New Zealand are much more vulnerable than those of Hokkaido in Japan, or those of northern Canada and Alaska. The industry's response to date has been to increase snow-making, snow grooming and terrain modification; to re-position resorts from winter to four-season; and to increase financial reliance on property and retail rather than lift tickets.

The coastal resort industry has responded to climate change much more slowly than ski resorts (Buckley 2008). Possible reasons include: lags in oceanic as compared to atmospheric changes; more distributed ownership of land and infrastructure in coastal settlements; controversy over liabilities and responsibilities; and misperceptions of likely climatic impacts (Buckley 2008). Tropical coral reefs are susceptible to bleaching from warm ocean 
temperatures, but to date this seems to have had relatively little effect on tourism. Most of the world's reef tourism destinations have experienced bleaching events, but the only serious effect on visitation seems to have been a 9\% drop at Palau (Glantz 2000, cited in Becken and Hay (2007). Experienced divers descend below the impacts of bleaching, and snorkellers seem unconcerned as long as they can still see fish. Future effects may be more severe if the ocean becomes increasingly acidic (Hoegh-Guldberg et al. 2007).

In forests, the main risks of climate change are from increased wildfires, which damage infrastructure and affect both access and attractiveness for tourism. In grasslands and deserts, droughts will affect populations and migrations of icon watchable wildlife species, as well as grazing pressure from domestic livestock, cultural landscapes, and the availability of water.

\section{Research Priorities}

The framework outlined above, as well as Hall's Probe suggest three major research themes at the destination scale. In urban tourist destinations, the key is the degree to which market share can be maintained by modifying the mix of activities and attractions. This is essentially a question of tourist behaviour, and there is already a considerable body of academic literature on tourism economics and geography, marketing and market research, and destination life-cycles which could be adapted to examine this question.

The second major theme is that of extreme weather events: their immediate impacts on tourist safety, attractions and infrastructure; and their longer term effects on competition between destinations. There is already a significant academic literature on disaster response and crisis management in tourism, which can be applied here.

The third and perhaps the most complex research theme is in predicting how natural attractions for tourism may be modified by climate change, and how tourists may change their travel patterns accordingly. This theme covers not only direct impacts of climate change on parks and beaches, water and wildlife; but also the indirect impacts on tourism as the social frameworks for access to these attractions change in response to changing climates (Buckley 2007). 


\section{Conclusions}

Climate change is indeed a highly significant issue for the global tourism industry: less acute than wars and terrorism, but larger scale and longer lasting. The subsectors of the tourism industry most affected by climate change will be smaller fixed-site operators or destinations which rely heavily on a single natural attraction - such as snow, reefs or wildlife - that happens to be particularly susceptible to climate change. Even in these cases, however, there are opportunities to re-position either the product or the target market segment so as to maintain revenue. The key in these cases will be forethought and innovation, to maintain a competitive position as corresponding adjustments occur worldwide.

As suggested by Becken in her further probe, climate change is likely to become so pervasive that it should be mainstreamed into all aspects of tourism research. Already, many analyses in tourism economics refer routinely to various climate change scenarios in much the same way as they routinely specify discount rates. Future research in tourism planning, policy and geography will no doubt refer to regional climate change patterns and predictions in a similar way.

In the short term, however, it would seem that if we were to pick a single top priority for research, it would be the social and environmental consequences of extreme weather events at destinations, and the flow-on effects for tourism. 


\section{References}

BECKEN, S. and HAY, J. (2007). Tourism and Climate Change: Risks and Opportunities. Clevedon. Channel View.

BECKEN, S. (2008). Climate Change - Beyond the Hype. Tourism Recreation Research 33(3):351-353.

BUCKLEY, R. (Ed) (2007). Climate Response. Gold Coast and Brisbane. Griffith University.

BUCKLEY, R. (2008). Misperceptions of Climate Change Damage Coastal Tourism: Case Study of Byron Bay, Australia. Tourism Review International (In press).

HALL, C. M. (2008). Tourism and Climate Change: Knowledge Gaps and Issues. Tourism Recreation Research 33(3): 339-350.

HALL, M. and HIGHAM, J. (Eds) (2005). Tourism, Recreation and Climate Change. Clevedon. Channel View.

HOEGH-GUldBERG, O., MUMBY, P. J., HOOTEN, A. J., STENECK, R. S., GREENFIELD, P., GOMEZ, E., HARVELL, C. D., SALE, P. F., EDWARDS, A. J., CALDEIRA, K., KNOWLTON, N., EAKIN, C. M., IGLESIAS-PRIETO, R., MUTHIGA, N., BRADBURY, R. H., DUBI, A. and HATZIOLOS, M. E. (2007). Coral Reefs under Rapid Climate Change and Ocean Acidification. Science 318 (5857): 1737-1742. 